\title{
PIEE
}

Premise: Journal of English Education and Applied Linguistics

https://fkip.ummetro.ac.id/journal/index.php/english

Maryansyah

\section{A STUDY ON ENGLISH STUDENTS' WILLINGNESS TO COMMUNICATE IN ENGLISH IN SOCIAL MEDIA}

\author{
By \\ Yupika Maryansyah \\ MUHAMMADIYAH UNIVERSITY OF BENGKULU \\ yupiedu@gmail.com
}

Received: March 2, 2019

Resent back: March 8, 2019

Accepted: March 30, 2019

Accepted: April 1, 2019
Reviewed: March 3, 2019

Reviewed: March 22, 2019

Revised; March 31, 2019

Published: April 2, 2019

Abstract:

This research aims to investigate factors affecting willingness to communicate in English in social media. This research was conducted in a descriptive method framework. Specifically, the research described factors that affect students' willingness to communicate in English in social media at English study program at the fourth semester of Muhammadiyah University of Bengkulu academic year 2018. The subjects of this research were fourth-semester students of English Education study program of Muhammadiyah University of Bengkulu Academic Year 2018 consisted of class $A, B$, and $C$. The populations of the study were 77 students. The instruments used were questionnaire and interview. The data obtained from both questionnaire and interview were then analyzed by the process of checking, classifying, determining, and analyzing the data by using the percentage formula. The results of the study showed that there were five factors affecting willingness to communicate in English in social media. They were self-confidence, personality, motivation, attitude, and anxiety. The dominant factor was motivation since it had the highest percentage. In addition, the study also revealed some reasons why students have the willingness to communicate through social media.

Keywords: Willingness to Communicate, Social Media.

\section{INTRODUCTION}

Every person in the world does communication in daily life. Communication is the most important thing in life. Because in life every people do communication to interact and express feeling and need in activities. Communication is an act by which one gives and receives information from another person about a person's needs, desires, perceptions, knowledge, of affective (Jhon \& Broni, 2014, p.1). And another definition was mentioned by Lunenburg (2010, p.1), that communication can be defined as a process of transmitting information and common understanding from one person to another. There are two forms of communication, first direct communication and the other is 
indirect communication. Direct communication is a process of communication that people do face to face with a partner. And second, indirect communication is a process of communication which is using communication tools. The target in communication is people know and understand each other what they talk about. To do communication, willingness to communicate is very important. In the field of language teaching and learning, according to McCroskey and Beatty (1986,p.279), willingness to communicate is defined as Individual's readiness to enter into discourse at a particular time with the specific person or persons using L2 language.

In modern days, people not only do communication face to face. There are many ways to do communication. So many applications used for communication in an online word like Facebook, Instagram, WhatsApp, Line, Twitter, etc. Social media is an online media where users do interaction and communication by internet connection network (Mayfield, 2008,p.5). Communication using social media is very interesting and simple. In social media, people are able to communicate with multiple people in one time. Social media can help and make people easy to do activities like: sharing information, chatting, work, Learning, and etc.

Social media is very famous among young people. By using social media, someone can communicate their feeling, ideas, information, and opinion. They may use social media to communicate anytime and anywhere they want (Hasse \& Young, 2010). This phenomenon is also occurring among students, including students at the English department of the Muhammadiyah University of Bengkulu. In accordance with this phenomenon, social media has become popular among students. The significance of this is that students can use any languages while communicating through social media. For a student of English, using English in social media will become fruitful because it can foster their capability in English. So that is why the researcher interested in conducting the research questioning students willingness to communicate in English in social media. This research is important because through this research it can be identified the factors affecting willingness to communicate in English, the dominant factors, and also causes that made students more willing to communicate in English in social media. This becomes strategic because by identifying the state of English students willingness to communicate in social media, it is hoped that teacher will get a benefit since they can design their learning based on this aspect.

Premise Journal Vol. 8 No 1, April 2019, e-ISSN: 2442-482x, p-ISSN: 2089-3345, page 31-45 Copyright@2019 by PJEE 
To get broader knowledge on a willingness to communicate in L2 learning, the researcher reviews some related theories. McIntyre, et al. (1998) states that as an individual's readiness to enter into discourse at a particular time with a specific person or persons, using an L2 and it is regarded as a final step before actual L2 use. Simic (2014,p..8) states that willingness to communicate in relation to an individual's general personality orientation toward talking. There are many factors that may facilitate or hinder communicating through L2 among which the psychological factors such as anxiety, attitudes, motivation, and self-confidence are very important. Kang et.al in Rostami (2016,p..2) argues that people can increase L2 learners' willingness to communicate by creating opportunities that might create an environment in which learners feel comfortable to initiate communication because learners with a higher willingness are more likely to use L2 in authentic communication, which can contribute to their successful second language acquisition. An increase in willingness to communicate is important to L2 acquisition Ellis (2004,p..551). This means that to get better both learning and acquisition of a language, learners must have the willingness to communicate first. However, people sometimes are reluctant to communicate because there are some aspects that may influence them before doing communication. As Maclntyre, et al. (1998) notice that there are some factors affecting willingness to communicate, they are self-confidence, personality, motivation, attitude, and anxiety. These factors also prevent people or students to have a conversation or have a chat in social media.

Social media is best understood as a group of new kinds of online media, which share most or all of the following characteristics: participant openness, conversation, and community connectedness (Freiermuth and Jarrel, 2006,p..190). Social media networks offer a straightforward way to converse with peers and get peer feedback, as well, which may influence a young adult's self-esteem. Social media may also make it easier for users to monitor activities of people they have not seen in a while as well as reconnecting with new and old friends. As interesting media, social media gives some benefits for all of the people in daily life like share information, search the information, and learn, in daily life especially to communicate with other people.

There are at least three popular social media used widely among people in the world nowadays. These three are also mostly used by students for daily communication, they are Facebook, Instagram, and WhatsApp. Facebook is a popular free social 
networking website that allows registered users to create profiles, upload photos and video, send messages and keep in touch with friends, family, and colleagues. And also it is an online social media networking service headquartered in Menlo Park, California. Its name comes from a colloquialism for the directory given to students at some American universities. Facebook was founded on February 4, 2004, by Mark Zuckerberg with his college roommates and fellow Harvard University students Eduardo Saverin, Andrew McCollum, Dustin Moskovitz and Chris Hughes (Boyd and Ellison 2007). The founders had initially limited the website's membership to Harvard students but later expanded it to colleges in the Boston area, the Ivy League, and Stanford University. It gradually added support for students at various other universities and later to their high-school students. Facebook now allows anyone who claims to be at least 13 years old worldwide to become a registered user of the website, although proof is not required.

Instagram is mobile, desktop, and Internet-based photo-sharing application and service that allows users to share pictures and videos either publicly, or privately to preapproved followers. Instagram was launched in the year 2000 by Kevin Systrom and Mike Krieger. According to the Instagram website, the Instagram application allows users to take photos from their mobile devices, subject it to a number of preinstalled filters, like changing the photo to greyscale for example, and upload it to the Instagram social network and other social networking platforms including Tumblr, Twitter, and Facebook. On Instagram, every people can communicate with other people like chatting, giving a comment, posting pictures and writing captions, or posting a short video, etc (Nukatta and Hayo, 2016).

Whatsapp is a proprietary, cross-platform instant messaging subscription service for smartphones and selected feature phones. It uses the internet for communication. In addition to text messaging, users can send messages, images, video, and audio media as well as their location. WhatsApp Inc. was founded in 2009 by Brian Acton and Jan Koum, both former employees at Yahoo!. The company is based in Mountain View, California and employs 55 people. As of October 2014, Whatsapp is the most globally popular messaging app more than 600 million users ( Mbukusa, 2018).

In the presentation of traditional English teaching activities, social media were indicated that they have prospective pedagogical benefit to improve language awareness, grammar, vocabulary, and fluency (Wu \& Wu, 2011), developing language 
competence (Dieu, 2004), and offering learners increased opportunities for language skill practice (Lee, 2010). In addition, when they were employed to implement communicative skill development, a number of studies showed that many types of social media could enable learners to interact with others using L2 (Toetenel, 2014). Also, social media has been agreed for their effects on affective variables and constantly showed a positive result. In general, previous studies verified that social media technologies could decrease learners' affective obstacles by allowing language learners to use L2 with more confidence (Thorne, 2009), increased motivation (Harrison \& Thomas, 2009), reduced anxiety (Stevenson \& Liu, 2010), decreased shyness (Bosch, 2009), and positive attitudes towards language learning (Thorne, 2009; Toetenel, 2014). These positive emotional variables are hypothesized to influence learners' willingness to communicate in L2.

There were several studies have been done related to willingness to communicate through social media in the context of language learning. First was a study conducted by Chotipaktanasook (2016), In this study, the researcher emphasized the work on the use of social media and effective benefits which were hypothesized to influence learners' willingness to communicate in L2. The study involved 40 students enrolling language courses at a university in Thailand. The subjects were asked to engage in one type of social media, which was Instagram during class time to reflect their learning experience in English. Questionnaires were administered and a follow-up interview was conducted for the evidence of the impact social media had on learners' emotional state. While the first phase of the investigation had yielded favorable findings, some of the findings from the second phase reported here also reaffirmed the usefulness of social media for lowering affective filter while increasing the level of willingness to communicate as a consequence.

The next was a study done by Le, Cunningham, and Watson (2018). This study investigated students' willingness to communicate with social presence. They had studied 18 high school students in Vietnam taking 6 weeks online course using Facebook and Skype. The subjects were interviewed individually before and after the course on their experiences to determine their perceptions of their willingness to communicate. The results of the study show that the students were more willing to use English spontaneously in the online setting. The point was that students eager to communicate in a less social presence situation.

Premise Journal Vol. 8 No 1, April 2019, e-ISSN: 2442-482x, p-ISSN: 2089-3345, page 31-45 Copyright@2019 by PJEE 
Although many studies have been done on the same subject, more empirical researches in many different specific contexts and settings are still needed to determine the willingness to communicate which as one important aspect that learners need to improve their English capability. This study was purposed to identify both affecting factors and causes that made students have the willingness to communicate on social media like facebook, Instagram, and Whatsapp. By having scientific identification on both issues, it is hoped that educators, especially at English department of the Muhammadiyah University of Bengkulu could create learning plans that foster students' willingness to communicate which eventually leads to the improvement of students' English mastery quality. Based on the previous description, this study is primarily questioning about, what are affecting factors that made students eager to communicate in online social media?

\section{METHOD}

\section{Design}

The design of this research is a descriptive study. This method was considered to be appropriate to describe the affecting factor of English students' willingness to communicate in English in social media and to trace their reasons to do communication in social media. By using this design, it was expected that the result of the study provides a deep and comprehensive analysis of the studied phenomenon.

\section{Participants}

The subjects of the research were all of the students of the fourth semester of English education study program of Muhammadiyah University of Bengkulu Academic Year of 2018/2019. The total number of research subjects was 77 students. These students were chosen as a participant of the study because they were considered to be the most appropriate samples in term of this study's purposes. The fourth-semester students were enrolling several subjects that allow researcher did an observation on the teaching-learning process involving online social media. 


\section{Instruments}

The instruments used in this research were questionnaire and interview. The questionnaire consisted of 20 items, including five factors affecting willingness to communicate namely, self-confident, personality, attitude, motivation, and anxiety. The Questionnaires was formed as Likert scale like format (strongly agree, agree, disagree, strongly disagree). The questionnaire was purposed to determine factors and the dominant factors affecting willingness to communicate and how the students' willingness to communicate in English in social media. The interview was used to cross-check, to support the data, and to trace reasons of willingness to communicate through social media consisting of open questions that required students to mention their reasoning.

\section{Data Collecting Technique}

The techniques for collecting data used in this study were questionnaire and interview. The questionnaire was purposed to draw subjects' responses by requesting them to choose one form of five options provided for each item. In administering this questionnaire the researcher came and distributed the questionnaire to students and asked them to complete the questionnaire as soon as possible. In addition, the researcher also administered an interview to get in detail data on students reason to do the online communication. The interview was conducted on 15 students from the population. By using this interview, the researcher gets supporting data for that obtained from the questionnaire because it was developed based on the same indicators used for the questionnaire. In completing this type of data collection process, students were asked to explain the reasons why they chose a particular social media channel to do communication.

\section{Data Analysis Technique}

The data were analyzed by the following steps; checking the students' responds, classifying the students' responds, and analyzing the data by using the percentage formula as described below. In addition, students' answers on the interview question were classified into the group to find a particular tendency. However; the qualitative data is analyzed by criteria content analysis or called CCA (Miles, Huberman, \& Saldana, 2014).

Premise Journal Vol. 8 No 1, April 2019, e-ISSN: 2442-482x, p-ISSN: 2089-3345, page 31-45 


\section{$\mathbf{P}=\mathbf{F} / \mathrm{N} \times 100 \%$}

Note :

P: percentage of respondents answer

F: frequency of students' factors influence willingness to communicate

$\mathrm{N}$ : the number of respondents

\section{RESULT AND DISCUSSION}

\section{Results}

Table 1. percentages of self confidence aspect

\begin{tabular}{|c|c|c|c|c|c|c|c|c|c|}
\hline Items & \multirow{2}{*}{$\mathrm{F}$} & \multicolumn{2}{|c|}{ Strongly Agree } & \multicolumn{2}{c|}{ Agree } & \multicolumn{2}{c|}{ Disagree } & \multicolumn{2}{c|}{$\begin{array}{c}\text { Strongly } \\
\text { Disagree }\end{array}$} \\
\cline { 3 - 10 } & & $\mathrm{F}$ & $\%$ & $\mathrm{~F}$ & $\%$ & $\mathrm{~F}$ & $\%$ & $\mathrm{~F}$ & $\%$ \\
\hline 1 & 77 & 20 & $26 \%$ & 52 & $67 \%$ & 3 & $4 \%$ & 2 & $3 \%$ \\
\hline 2 & 77 & 20 & $26 \%$ & 45 & $58 \%$ & 10 & $13 \%$ & 2 & $3 \%$ \\
\hline 3 & 77 & 18 & $23 \%$ & 49 & $64 \%$ & 8 & $10 \%$ & 2 & $3 \%$ \\
\hline 4 & 77 & 22 & $28 \%$ & 47 & $61 \%$ & 6 & $8 \%$ & 2 & $3 \%$ \\
\hline
\end{tabular}

The table depicts self-confidence aspect respectively based on the rank of percentages. It can be seen from the table that on item 1, 52 students chose to agree (67\%), 20 students chose strongly agree (26\%), 3 students chose to disagree (4\%), and 2 students chose strongly disagree (3\%). The second is item no 3 with 49 students agreed (64\%), 18 students strongly agreed (23\%), 8 students disagreed (10\%), and 2 students strongly disagreed (3\%). The third is item no 4 with 47 students responded with agree (61\%), 22 students responded with strongly agree (28\%), 6 students responded with disagree (8\%), and 2 students responded with strongly disagree (3\%). And the last, as the lowest in percentage, is item no 2 with 45 students answered agree $(58 \%)$, students answered strongly agree (26\%), 10 students answered disagree (13\%), and 2 students answered strongly disagree (3\%).

Table 2. percentages of personality aspect

\begin{tabular}{|c|c|c|c|c|c|c|c|c|c|}
\hline Items & \multirow{2}{*}{$\mathrm{F}$} & \multicolumn{2}{|c|}{ Strongly Agree } & \multicolumn{2}{c|}{ Agree } & \multicolumn{2}{c|}{ Disagree } & \multicolumn{2}{c|}{$\begin{array}{c}\text { Strongly } \\
\text { Disagree }\end{array}$} \\
\cline { 3 - 10 } & & $\mathrm{F}$ & $\%$ & $\mathrm{~F}$ & $\%$ & $\mathrm{~F}$ & $\%$ & $\mathrm{~F}$ & $\%$ \\
\hline 5 & 77 & 19 & $25 \%$ & 48 & $62 \%$ & 6 & $8 \%$ & 4 & $5 \%$ \\
\hline
\end{tabular}




\begin{tabular}{|c|c|c|c|c|c|c|c|c|c|}
\hline 6 & 77 & 21 & $27 \%$ & 49 & $64 \%$ & 5 & $6 \%$ & 2 & $3 \%$ \\
\hline 7 & 77 & 22 & $28 \%$ & 40 & $52 \%$ & 13 & $17 \%$ & 2 & $3 \%$ \\
\hline 8 & 77 & 17 & $22 \%$ & 44 & $57 \%$ & 14 & $18 \%$ & 2 & $3 \%$ \\
\hline
\end{tabular}

Based on the table, item no 6 with 49 students answered agree (64\%) was in the first rank of percentage, 21 students chose strongly agree (27\%), 5 students chose to disagree (6\%), and 2 students chose strongly disagree (3\%). The second is item no 5 with 48 students answered agree (62\%), 19 students answered strongly agree (25\%), 6 students answered disagree ( $8 \%$ ), and 4 students answered strongly disagree (5\%). The third is item no 8 with 44 students answer agree (57\%), 17 students answered strongly agree (22\%), 14 students answered disagree (18\%), and 2 students answered strongly disagree (3\%). And the last is item no 7 with 40 students answered agree (52\%), 22 students answered strongly agree (28\%), 13 students answered disagree (17\%), and 2 students answered strongly disagree (3\%).

Table 3. percentages of motivation aspect.

\begin{tabular}{|c|c|c|c|c|c|c|c|c|c|}
\hline Items & \multirow{2}{*}{$\mathrm{F}$} & \multicolumn{2}{|c|}{ Strongly Agree } & \multicolumn{2}{c|}{ Agree } & \multicolumn{2}{c|}{ Disagree } & \multicolumn{2}{c|}{$\begin{array}{c}\text { Strongly } \\
\text { Disagree }\end{array}$} \\
\cline { 3 - 10 } & & $\mathrm{F}$ & $\%$ & $\mathrm{~F}$ & $\%$ & $\mathrm{~F}$ & $\%$ & $\mathrm{~F}$ & $\%$ \\
\hline 9 & 77 & 26 & $34 \%$ & 43 & $56 \%$ & 7 & $9 \%$ & 1 & $1 \%$ \\
\hline 10 & 77 & 17 & $22 \%$ & 51 & $66 \%$ & 7 & $9 \%$ & 2 & $3 \%$ \\
\hline 11 & 77 & 22 & $29 \%$ & 46 & $60 \%$ & 8 & $10 \%$ & 1 & $1 \%$ \\
\hline 12 & 77 & 25 & $32 \%$ & 44 & $57 \%$ & 7 & $9 \%$ & 1 & $1 \%$ \\
\hline
\end{tabular}

The table shows that item no 10 with 51 students had been responded with agree (66\%), with 17 students had been responded strongly agree (22\%), with 7 students had been responded disagree (9\%), and with 2 students had been responded strongly disagree (3\%). The second is item no 11 with 46 students answered agree (60\%), 22 students answered strongly agree (29\%), 8 students answered disagree (10\%), and 1 student answered strongly disagree (1\%). The third is item no 12 with 44 students answered agree (57\%), 25 students answered strongly agree (32\%), 7 students answered disagree (9\%), and 1 student answered strongly disagree (1\%). And the last is item no 9 with 43 students answer agree (56\%), 26 students answered strongly agree (34\%), 7 students answered disagree (9\%), and 1 student answered strongly disagree (1\%).

Premise Journal Vol. 8 No 1, April 2019, e-ISSN: 2442-482x, p-ISSN: 2089-3345, page 31-45 Copyright@2019 by PJEE 
Table 4. percentages of attitude aspect

\begin{tabular}{|c|c|c|c|c|c|c|c|c|c|}
\hline Items & \multirow{2}{*}{$\mathrm{F}$} & \multicolumn{2}{|c|}{ Strongly Agree } & \multicolumn{2}{c|}{ Agree } & \multicolumn{2}{c|}{ Disagree } & \multicolumn{2}{c|}{$\begin{array}{c}\text { Strongly } \\
\text { Disagree }\end{array}$} \\
\cline { 3 - 10 } & & $\mathrm{F}$ & $\%$ & $\mathrm{~F}$ & $\%$ & $\mathrm{~F}$ & $\%$ & $\mathrm{~F}$ & $\%$ \\
\hline 13 & 77 & 16 & $21 \%$ & 43 & $55 \%$ & 16 & $21 \%$ & 2 & $3 \%$ \\
\hline 14 & 77 & 23 & $30 \%$ & 40 & $51 \%$ & 12 & $16 \%$ & 2 & $3 \%$ \\
\hline 15 & 77 & 21 & $27 \%$ & 44 & $57 \%$ & 10 & $13 \%$ & 2 & $3 \%$ \\
\hline 16 & 77 & 21 & $27 \%$ & 48 & $62 \%$ & 7 & $9 \%$ & 1 & $1 \%$ \\
\hline
\end{tabular}

The table depicts the percentage of students' answers to the tendency that attitude factor affecting students' willingness to communicate in English in social media. Item no 16 with 48 students answered agree (62\%), 21 students answered strongly agree (27\%), 7 students answered disagree (9\%), and 2 students answered strongly disagree (3\%). The second is item no 15 with 44 students answered agree (57\%), 21 students answered strongly agree (27\%), 10 students answered disagree (13\%), and 2 students answered strongly disagree (3\%). The third is item no 13 with 43 students answered agree (55\%), 16 students answered strongly agree (21\%), 16 students answered disagree (21\%), and 2 students answered strongly disagree (3\%). And the last is item no 14 with 40 students answer agree (51\%), 23 students answered strongly agree (30\%), 10 students answered disagree (13\%), and 2 students answered strongly disagree $(3 \%)$.

Table 5. percentages of anxiety aspect

\begin{tabular}{|c|c|c|c|c|c|c|c|c|c|}
\hline Items & \multirow{2}{*}{$\mathrm{F}$} & \multicolumn{2}{|c|}{ Strongly Agree } & \multicolumn{2}{c|}{ Agree } & \multicolumn{2}{c|}{ Disagree } & \multicolumn{2}{c|}{$\begin{array}{c}\text { Strongly } \\
\text { Disagree }\end{array}$} \\
\cline { 3 - 10 } & & $\mathrm{F}$ & $\%$ & $\mathrm{~F}$ & $\%$ & $\mathrm{~F}$ & $\%$ & $\mathrm{~F}$ & $\%$ \\
\hline 17 & 77 & 14 & $18 \%$ & 28 & $36 \%$ & 32 & $42 \%$ & 3 & $4 \%$ \\
\hline 18 & 77 & 13 & $17 \%$ & 22 & $29 \%$ & 34 & $44 \%$ & 7 & $9 \%$ \\
\hline 19 & 77 & 13 & $17 \%$ & 23 & $30 \%$ & 34 & $44 \%$ & 9 & $12 \%$ \\
\hline 20 & 77 & 19 & $25 \%$ & 41 & $53 \%$ & 13 & $17 \%$ & 4 & $5 \%$ \\
\hline
\end{tabular}

The table shows that as the first rank, on item no 20, there were 41 students answered agree (53\%), 19 students answered strongly agree (25\%), 13 students answered disagree (17\%), and 4 students answered strongly disagree (5\%). The second is item no 17 with 28 students answered agree (36\%), 14 students answered strongly 
agree (18\%), 32 students answer disagree (42\%), and 3 students answered strongly disagree (4\%). The third is item no 19 with 23 students answered agree (30\%), 13 students answered strongly agree (17\%), 34 students answered disagree (44\%), and 9 students answered strongly disagree (12\%). And the last is item no 18 with 22 students answered agree (29\%), 14 students answered strongly agree (18\%), 32 students answered disagree (42\%), and 3 students answered strongly disagree (4\%).

Table 5. Total percentages.

\begin{tabular}{lllllllc}
\hline No & Items & $\begin{array}{l}\text { Strongly } \\
\text { Agree }\end{array}$ & Agree & Disagree & $\begin{array}{l}\text { Strongly } \\
\text { Disagree }\end{array}$ & $(+)$ & $(-)$ \\
\hline $\mathbf{1}$ & $\begin{array}{l}\text { Self } \\
\text { Confidence }\end{array}$ & $25,75 \%$ & $62,50 \%$ & $8,75 \%$ & $3 \%$ & $88,25 \%$ & $11,75 \%$ \\
$\mathbf{2}$ & Personality & $25,50 \%$ & $58,75 \%$ & $12,25 \%$ & $3,50 \%$ & $84,25 \%$ & $15,75 \%$ \\
$\mathbf{3}$ & Motivation & $29,25 \%$ & $59,75 \%$ & $9,25 \%$ & $1,5 \%$ & $89 \%$ & $10.75 \%$ \\
$\mathbf{4}$ & Attitude & $26,25 \%$ & $56,25 \%$ & $14,75 \%$ & $2,5 \%$ & $82,5 \%$ & $17,25 \%$ \\
$\mathbf{5}$ & Anxiety & $19,25 \%$ & $37 \%$ & $36,75 \%$ & $7,5 \%$ & $56,25 \%$ & $44,25 \%$
\end{tabular}

From the table above the researcher showed positive and negative result.

\section{Results of Interview}

Base on the interview that had been done on 15 students at fourth semester of English education study program at Muhammadiyah University of Bengkulu academic year 2018/2019, the researcher found that students did the communication through social media because they felt that by using social media they can decrease their shyness, nervous, worry and all level fear of anxiety. They felt more comfortable, confident, easy to use social media in communication. They also admitted that they were more confident in social media than in the classroom.

\section{Discussion}

Based on the percentage of all factors, we can see that the first factor that affects students' willingness to communicate in English in social media is motivation with the highest percentage of $89 \%$. This is in line whit the result of interview since most students said that communication by using social media like Facebook, Instagram, and WhatsApp was very interesting, easy, and enjoyable. This finding is also in accordance with what has found by Harrison \& Thomas (2009). Who did a study on the using of social media technologies in learning English? It is logical if students said that having 
a conversation or chat through online social media is enjoyable. There is some reason for this, first is the absence of feelings that may disturb them in direct communication in L2 languages like anxiety, a worry of a mistake on grammar or pronunciation. Students may have a harder burden if they are having a conversation with their teachers or lecturers because they are afraid of judgments leading to their mistake, moreover a judgment from their lecturers for instance.

The second thing that made students were happy to communicate on social media is the convenience aspect of doing communication online. Students may do communication wherever and whenever they want. This becomes possible because of the development of current technology. Everyone can do communication by using communication tools like gadgets. In this respect, the result of this study may support what had been stated by Thorne (2009) that social media technologies could decrease learners' affective obstacles by allowing language learners to use L2 with more confidence (Thorne, 2009).

In addition, the results of this study, in general, was also in line with the study results found by Chotipaktanasook (2016), Le, Cunningham, and Watson (2018). Both studies found the same results that students feel more comfortable to do communication in online social media because they feel a lack of social presence. They were afraid of doing mistake on face to face communication. Elsewhere, the current study found that the most dominant factor affecting students to communicate was motivation. It can be seen that the reason why students' motivation increased when they had online communication, it was because they could lower their anxiety within the absence of face to face communication. In this term, in the end, students could increase their willingness to communicate.

Even the results of this study could not generalize all students and all setting of the study, at least it made clear one thing, that is the possibility to utilize social media in improving students' English capability. This statement was supported by the fact that students were happy and motivated to communicate on online social media. This will give more opportunities for students to practice their language skills (Lee, 2010). So this is also a chance for teachers or lecturers to foster students willingness to communicate by including online social media in their teaching and learning plans. 


\section{CONCLUSION}

Based on the results of the study, there were five factors possibly affect willingness to communicate in English in social media. They are self-confidence, personality, motivation, attitude, and anxiety. However, the dominant factor was motivation. In addition, the main reason among several reasons that students argued on why they do online communication through social media was the ease and convenience of it. Regarding, educators of English could take benefit from this phenomenon. Because students were happy and enjoyable of doing online communication, educators are recommended to employ social media in their learning and teaching activities.

\section{BIO-PROFILE}

Yupika Maryansyah is a lecturer at the English Study Program of the Muhammadiyah University of Bengkulu. He obtained his Master degree in English language teaching from Universitas Negeri Padang (UNP). His research interests are English language teaching, linguistics, teacher education, and professional development. Corresponding email: yupiedu@gmail.com 


\section{REFERENCES}

Bosch, T. E. (2009). Using online social networking for teaching and learning: Facebook uses at the University of Cape Town. Communication: South African Journal for Communication Theory and Research, 35(2), 185-200.

Boyd D. M., Ellison N. B. (2007). Social network sites: Definition, history, and scholarship. Journal of Computer-Mediated Communication, (13) 1, 11-23.

Chotipaktanasook, Nuttakritta (2016). Using Social Media In The EFL Classroom For The Enhancement Of Low Affective Filter And Willingness To Communicate. Retrieved from https://www.fas.nus.edu.sg/cls/CLaSIC/clasic2016/PROCEEDINGS/chotipaktanasook $\underline{\text { nuttakritta.pdf }}$

Dieu, B. (2004). Blogs for language learning. Essential Teacher. 1(4), 26-30.

Freiermuth, M., \& Jarrell, D. (2006). Willingness to communicate: Can online chat help? International Journal of Applied Linguistics, (16) 2, 189-212.

Harrison, R., \& Thomas, M. (2009). Identify in online communities: Social networking sites and language learning. International Journal of Emerging Technologies \& Society. 7(2), 109-124.

Hasse, Q. A., \& Young, L. A. (2010). Uses and Gratifications of Social Media: A Comparison of Facebook and Instant Messaging. Journal of Bulletin of Science, Technology \& Society. 54(1), 119-152.

Kang, S. J. in Rostami, G, et al. (2016). The Relationship between Language Proficiency and Willingness to Communicate in English in an Iranian EFL Context. Journal of Applied Linguistics and Language Research (3) 2, 166-176.

Le, T.V., Cunningham, U., \& Watson, K.(2018). The relationship between willingness to communicate and social presence in an online English language course. The JALT CALL Journal, 14(1), 43-59.

Lee, L. (2010). Fostering reflective writing and interactive exchange through blogging in an advanced language course. ReCALL, (22) 2, 212-222.

Lunembrug, Fred C. (2010). Communication: The Process, Barriers, And Improving Effectiveness. Schooling (1) 1, 2-15.

MacIntyre, P. D., Clément, R., Dörnyei, Z., \& Noels, K. A. (1998). Willingness to communicate in an L2: A situational model of L2 confidence and affiliation. The Modern Language Journal. (82) 545-562.

Mayfield, Antony. (2008) What Is social media? Published by Icrossing. USA: Prentice Hall.

Mbukusa, Nchindo Richardson (2018). Perceptions of students' on the Use of WhatsApp in Teaching Methods of English as Second Language at the University of Namibia. Journal of Curriculum and Teaching. (7) 2.112-119.

Premise Journal Vol. 8 No 1, April 2019, e-ISSN: 2442-482x, p-ISSN: 2089-3345, page 31-45

Copyright@2019 by PJEE 
McCroskey, J. C., \& Beatty, J. Michael. (1986). Oral Communication Apprehension. Journal of Applied Linguistics and Language Research (3) 2, 166-176.

Miles, M. B., Huberman, A. M., \& Saldana, J. (2014). Qualitative Data Analysis A Methods Sourcebook (Third ed.). LA: SAGE Publication.

Nukatta, C and Hayo, R. (2016). Willingness to Communicate in Social Media: An Investigation of the Long-term Effects. Asian EFL Journal of Research Articles. (18) 4 33-45

Simic, I. (2014). Willingness to Communicate: A comparison between Austrian and Serbian students. Graz: zur Erlangung des akademichen Grades.

Stevenson, M. P., \& Liu, M. (2010). Learning a language with Web 2.0: Exploring the use of social networking features of foreign language learning websites. CAELL Journal. 27(2), 233-259.

Thorne, S. L. (2009). Community, semiotic flows, and mediated contribution to activity. Language Teaching, 42(1), 81-94.

Toetenel, L. (2014). Social networking: a collaborative open educational resource. Computer Assisted Language Learning, 27(2), 149-162.

Wu, H.-J., \& Wu, P.-L. (2011). Learners' perceptions on the use of blogs for EFL learning. US-China Education Review, A3, 323-330. 